\title{
The Outlook for Asian Dairy Markets: The Role of Demographics, Income, and Prices
}

\author{
Fengxia Dong
}

\section{Working Paper 05-WP 399}

June 2005

\author{
Center for Agricultural and Rural Development \\ lowa State University \\ Ames, lowa 50011-1070 \\ www.card.iastate.edu
}

Fengxia Dong is an associate scientist at the Center for Agricultural and Rural Development.

This paper is available online on the CARD Web site: www.card.iastate.edu. Permission is granted to reproduce this information with appropriate attribution to the authors.

For questions or comments about the contents of this paper, please contact Fengxia Dong, 571 Heady Hall, lowa State University, Ames, IA 50011-1070; Ph: 515-294-0470; Fax: 515-294-6336; E-mail: fdong@iastate.edu.

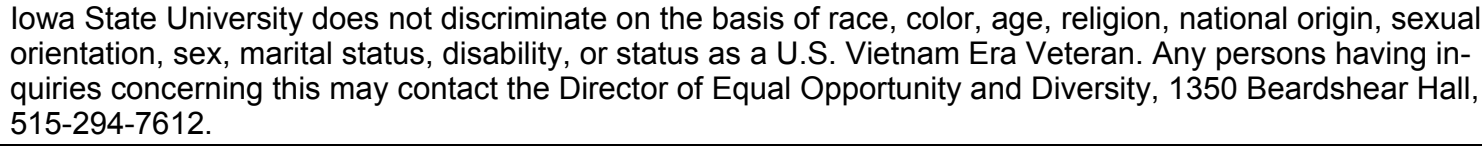
orientation, sex, marital status, disability, or status as a U.S. Vietnam Era Veteran. Any persons having inquiries concerning this may contact the Director of Equal Opportunity and Diversity, 1350 Beardshear Hall, 515-294-7612. 


\begin{abstract}
The paper first presents a 10-year outlook for major Asian dairy markets (China, India, Indonesia, Japan, South Korea, Malaysia, the Philippines, Thailand, and Vietnam) based on a world dairy model. Then, using Heien and Wessells's technique, dairy product consumption growth is decomposed into contributions generated by income growth, population growth, price change, and urbanization and these contributions are quantified. Using the world dairy model, the paper also analyzes the impacts of alternative assumptions of higher income levels and technology development in Asia on Asian dairy consumptions and world dairy prices. The outlook projects that Asian dairy consumption will continue to grow strongly in the next decade. The consumption decomposition suggests that the growth would be mostly driven by income and population growth and, as a result, would raise world dairy prices. The simulation results show that technology improvement in Asian countries would dampen world dairy prices and meanwhile boost domestic dairy consumption.
\end{abstract}




\section{THE OUTLOOK FOR ASIAN DAIRY MARKETS: THE ROLE OF DEMOGRAPHICS, INCOME, AND PRICES}

\section{Introduction}

With strong economic growth, population growth (see Table 1), and a shift toward higher-valued foods and livestock products, Asian dairy demand has been expanding dramatically. Compared with Western countries, however, Asian dairy per capita consumption is still relatively low. This fact implies tremendous potential for future growth in Asian dairy demand and consequently in domestic supply and world trade.

Given this situation, however, very few studies have been conducted to project future Asian dairy markets and determine the forces driving Asian dairy consumption. The existing studies include Rae's (1997) projection of dairy consumption in East Asia for the period 1992-2002. In his study, Rae finds that total consumption of dairy products may increase in East Asia, and such an increase is mainly due to rises in per capita consumption or population growth. The limitation of this study is that the projection only takes account of changes in population and per capita expenditure. Other factors such as relative prices and urbanization are not included. In addition, it is outdated. Ma and Rae (2003) make projections of China's dairy products consumption by 2005 but with problems similar to those in Rae's study. To fill the gap between these limited studies and the continuing prospects for strong demand and dynamic changes in Asian dairy markets, this study aims to provide an outlook for major Asian dairy markets and an improved understanding of the demand for dairy products, which are essential for future policy analysis.

This paper has three objectives. The first is to present a 10-year outlook for major Asian dairy markets for five product categories (fluid milk, cheese, butter, non-fat dry [NFD] milk, and whole milk powder [WMP]). This outlook is based on projections gen-

erated by the Food and Agricultural Policy Research Institute (FAPRI) world dairy model and expands the country coverage relative to the original 2005 FAPRI outlook. In terms of the model's coverage of Asia, the major dairy producing and consuming countries are 
TABLE 1. Demographic and economic information of Asian countries for selected years

\begin{tabular}{|c|c|c|c|c|}
\hline & 1970 & 1980 & 1990 & 2000 \\
\hline \multicolumn{5}{|l|}{ China } \\
\hline Population & 820.4033 & 984.7365 & 1148.364 & 1268.853 \\
\hline Urban & 162.6491 & 221.8169 & 300.183 & 387.2438 \\
\hline Rural & 657.7541 & 762.9195 & 838.7115 & 875.2305 \\
\hline Real GDP & & 912.3132 & 694.0368 & 1050.966 \\
\hline Private Expenditure & & 152.0335 & 190.5988 & 490.7731 \\
\hline Urban & & 54.73839 & 83.32581 & 265.0548 \\
\hline Rural & & 97.29509 & 107.273 & 225.7182 \\
\hline CPI & & & 54.57609 & 109.1472 \\
\hline \multicolumn{5}{|l|}{ India } \\
\hline Population & 555.0428 & 687.0293 & 841.6551 & 1002.708 \\
\hline Real GDP & 517.5258 & 668.2183 & 526.6888 & 350.0492 \\
\hline CPI & 12.28615 & 26.01971 & 60.79981 & 143.9608 \\
\hline \multicolumn{5}{|l|}{ Indonesia } \\
\hline Population & 122.2918 & 154.3788 & 188.0054 & 224.1384 \\
\hline Real GDP & 241.3042 & 300.9963 & 174.7783 & 55.96917 \\
\hline CPI & 5.951283 & 28.64517 & 65.25382 & 239.0093 \\
\hline \multicolumn{5}{|l|}{ Japan } \\
\hline Population & 104.345 & 116.8073 & 123.5374 & 126.6998 \\
\hline Real GDP & & & 3185.072 & 4942.959 \\
\hline CPI & 32.29845 & 76.30487 & 93.46925 & 101.5058 \\
\hline \multicolumn{5}{|l|}{ Malaysia } \\
\hline Population & 10.91022 & 13.76435 & 17.50361 & 21.79329 \\
\hline Real GDP & 11.6261 & 36.3711 & 52.31211 & 73.62346 \\
\hline CPI & 33.84456 & 60.00441 & 82.32606 & 116.6766 \\
\hline \multicolumn{5}{|l|}{ The Philippines } \\
\hline Population & 38.6037 & 50.94018 & 64.31812 & 79.73983 \\
\hline Real GDP & 138.0059 & 192.8669 & 70.43201 & 51.34003 \\
\hline CPI & 4.64607 & 18.23747 & 62.12483 & 141.0076 \\
\hline \multicolumn{5}{|l|}{ South Korea } \\
\hline Population & 32.241 & 38.124 & 42.869 & 47.26128 \\
\hline Real GDP & 180.9944 & 189.2854 & 372.2003 & 413.2815 \\
\hline CPI & 8.947392 & 40.32798 & 74.03792 & 121.5067 \\
\hline \multicolumn{5}{|l|}{ Thailand } \\
\hline Population & & 47.02576 & 55.25003 & 62.35204 \\
\hline Real GDP & & 63.50138 & 108.1996 & 106.7378 \\
\hline CPI & & 51.46416 & 79.11152 & 123.0692 \\
\hline \multicolumn{5}{|l|}{ Vietnam } \\
\hline Population & & 53.7152 & 67.2827 & 79.06041 \\
\hline Real GDP & & & 23.82546 & 22.60772 \\
\hline CPI & & & & 119.725 \\
\hline
\end{tabular}

Note: Population is in millions; real GDP and expenditure are in billions of U.S. dollars; CPI=100 for year 1995. 
included, namely, China, India, Indonesia, Japan, South Korea, Malaysia, the Philippines, Thailand, and Vietnam, of which Thailand and Vietnam are additional to the original 2005 FAPRI outlook. The second objective of this paper is to evaluate the impacts of determinants of dairy demand and their roles as the primary sources of demand changes. Following Heien and Wessells (1988), dairy product consumption growth is decomposed into contributions generated by income growth, population growth, price change, and urbanization, and these contributions are quantified. The third and final objective is to evaluate the impacts of alternative assumptions on income and technology changes in Asia on Asian dairy consumptions and world dairy prices. These impacts are quantified by running stimulations using the FAPRI world dairy model.

This study finds that Asian dairy consumption will continue to grow strongly in the next decade, and the growth is expected to be driven mostly by the Asia's income and population growth. The negative effects of elevated world dairy prices on Asian dairy demand are expected to be relatively modest. Moreover, the income growth in Asian countries will not only increase Asian dairy demand but also raise world dairy prices; technology improvement, which increases domestic supply, will dampen world dairy prices and in the meantime boost domestic dairy consumption.

The next section briefly describes the situation in the Asian dairy industry to date and is followed by a summary of the outlook for Asian dairy markets over the next decade based on the model projections. The third section presents the decomposition analysis of Asian dairy demand changes, and the fourth section analyzes the impacts of income and technology changes on future Asian dairy consumption and world dairy prices. Finally, a summary of the results for the analysis is presented.

\section{The Asian Dairy Industry Situation}

\section{Dairy Consumption}

The Asian diet is relatively low in meat and dairy foods, and plant-based foods contribute the core of the daily intake. Besides dietary habits, lactose intolerance discourages many Asian people from consuming milk. The history of Asian dairy consumption is very short (Song and Sumner 1999) but with an upward trend. Table 2 shows the per capita dairy consumption of Asian countries in selected years. The average per capita dairy 
TABLE 2. Dairy consumption in Asian countries for selected years (kg per capita)

\begin{tabular}{|c|c|c|c|c|}
\hline & 1970 & 1980 & 1990 & 2000 \\
\hline \multicolumn{5}{|l|}{ China } \\
\hline Milk & & 2.25 & 1.69 & 3.47 \\
\hline Butter & 0.02 & 0.04 & 0.06 & 0.07 \\
\hline Cheese & 0.06 & 0.07 & 0.14 & 0.17 \\
\hline NFD & & & 0.04 & 0.06 \\
\hline WMP & & & 0.26 & 0.44 \\
\hline \multicolumn{5}{|l|}{ India } \\
\hline Milk & 15.88 & 21.83 & 31.78 & 33.14 \\
\hline Butter & 0.78 & 0.87 & 1.2 & 2.17 \\
\hline NFD & 0.07 & 0.1 & 0.1 & 0.17 \\
\hline \multicolumn{5}{|l|}{ Indonesia } \\
\hline Milk & 1.41 & 2.15 & 2.86 & 1.26 \\
\hline Butter & 0 & 0.09 & 0.02 & 0.05 \\
\hline Cheese & 0 & 0.01 & 0.01 & 0.03 \\
\hline NFD & 0.17 & 0.26 & 0.06 & 0.24 \\
\hline WMP & 0 & 0.08 & 0.02 & 0.28 \\
\hline \multicolumn{5}{|l|}{ Japan } \\
\hline Milk & 25.14 & 33.71 & 40.96 & 39.23 \\
\hline Butter & 0.4 & 0.52 & 0.71 & 0.66 \\
\hline Cheese & 0.4 & 0.71 & 1.12 & 1.89 \\
\hline NFD & 1.12 & 2.05 & 2.19 & 1.85 \\
\hline \multicolumn{5}{|l|}{ Malaysia } \\
\hline Milk & 2.82 & 2.13 & 1.92 & 1.57 \\
\hline Butter & 0.18 & 0.06 & 0.1 & 0.44 \\
\hline Cheese & 0.03 & 0.03 & 0.09 & 0.22 \\
\hline NFD & 2.57 & 0.78 & 2.7 & 3.33 \\
\hline WMP & 1.05 & 4.28 & 1.95 & 2.14 \\
\hline \multicolumn{5}{|l|}{ Philippines } \\
\hline Milk & 0.65 & 0.59 & 0.34 & 0.39 \\
\hline Butter & 0.12 & 0.16 & 0.13 & 0.15 \\
\hline Cheese & 0.1 & 0.09 & 0.13 & 0.2 \\
\hline NFD & 0.85 & 1.37 & 1.17 & 1.4 \\
\hline WMP & 0.42 & 0.4 & 0.77 & 0.61 \\
\hline \multicolumn{5}{|c|}{ South Korea } \\
\hline Milk & 0.46 & 5.66 & 28.17 & 31.96 \\
\hline Butter & 0.05 & 0.22 & 1.02 & 1.18 \\
\hline Cheese & 0 & 0 & 0 & 0.93 \\
\hline NFD & 0.31 & 0.8 & 0.93 & 0.91 \\
\hline WMP & 0.01 & 0.29 & 0.2 & 0.12 \\
\hline \multicolumn{5}{|l|}{ Thailand } \\
\hline Milk & & 0.64 & 1.82 & 7.94 \\
\hline Butter & & 0.10 & 0.18 & 0.20 \\
\hline Cheese & & 0.00 & 0.08 & 0.05 \\
\hline NFD & & 0.53 & 0.86 & 0.85 \\
\hline WMP & & 0.24 & 0.28 & 0.50 \\
\hline
\end{tabular}


The Outlook for Asian Dairy Markets: The Role of Demographics, Income, and Prices / 5

TABLE 2. Continued

\begin{tabular}{lcccc}
\hline & $\mathbf{1 9 7 0}$ & $\mathbf{1 9 8 0}$ & $\mathbf{1 9 9 0}$ & $\mathbf{2 0 0 0}$ \\
\hline Vietnam & & & \\
Milk & & 0.75 & 0.87 & 1.03 \\
Butter & 0.02 & 0.02 & 0.06 \\
Cheese & 0.00 & 0.00 & 0.02 \\
NFD & 0.07 & 0.04 & 0.34 \\
WMP & 0.00 & 0.01 & 0.45 \\
\hline
\end{tabular}

consumption (including fluid milk, butter, cheese, NFD, and WMP) in the last decade for the major dairy markets was $4.5 \mathrm{~kg}$ in China, $35.7 \mathrm{~kg}$ in India, $2.1 \mathrm{~kg}$ in Indonesia, 44.2 $\mathrm{kg}$ in Japan, $7.7 \mathrm{~kg}$ in Malaysia, $2.4 \mathrm{~kg}$ in the Philippines, $35.2 \mathrm{~kg}$ in South Korea, $9.8 \mathrm{in}$ Thailand, and $1.8 \mathrm{~kg}$ in Vietnam. This contrasts with per capita consumption of $105 \mathrm{~kg}$ in the EU-15, $120 \mathrm{~kg}$ per capita in Australia, and $113 \mathrm{~kg}$ per capita in the United States. ${ }^{1}$

It is notable that Japan and South Korea, which have higher disposable income and are more Westernized, have much higher consumption than other Asian countries except India. Japanese and South Korean milk consumption grew rapidly prior to 1990, concurring with the countries' fast economic growth and boosted by their school milk programs. After 1990, the increase in milk consumption slowed considerably, and the consumption has recently reached a mature stage. However, cheese consumption in the two countries has just begun to grow, increasing from $0.4 \mathrm{~kg}$ per capita in 1970 to about current $2 \mathrm{~kg}$ per capita in Japan and from negligible amounts in 1990 to currently over $1.2 \mathrm{~kg}$ per capita in South Korea. Cheese consumption in these two countries is mainly boosted by the rapid growth in fast-food and pizza restaurants as well as aggressive sales promotion and educational campaigns (JETRO 1999). However, butter consumption is still very limited, as butter is only used as a spread for bread (Campo and Beghin 2005). Japanese and South Korean consumers today are more conscious of quality, safety, taste, and freshness of dairy products.

Compared with Japan and South Korea, other Asian countries, which share a number of cultural, agricultural, and dietary habits in common, are expected to experience similar changes and increase their dairy consumption as their income grows and dietary preferences shift.

China's dairy consumption has increased tremendously. The strong growth in China's economy, contemporary urbanization and Westernization of their diet, and the 
improved awareness of dairy nutrition as well as associated transformations have facilitated China's rapid growth in dairy consumption (Fuller et al. 2005). However, China's dairy consumption is still one of the lowest in the world, as these changes are slow across the country. In addition, a weak infrastructure for distribution limits consumers' access to fresh products, especially for people living in small cities or rural areas. Currently in rural areas, milk is still considered a product for infants and the sick (Zhou, Tian, and Zhou 2002), while it is changing from a supplement food to a daily food in urban areas. The majority of Chinese dairy consumption takes place in metropolitan areas. And sugar-added WMP is being replaced by liquid milk and formulas for different ages and different nutrition-deficit groups. As Chinese supermarket chains with centralized distribution and procurement and door-to-door delivery develop, and given expanded operations of individual chains, dairy processors will have access to consumers throughout China (Fuller and Beghin 2004). Moreover, with the help of the government's school milk program and other promotional activities, milk consumption is beginning to develop in other areas.

Milk and dairy products are an important source of protein to a large segment of the Indian population, as approximately 210 million Hindus are lacto-vegetarians (Bhaskaran 1996). Dairy products have considerable symbolic value in Hindu religious and social life. In addition those who are lacto-vegetarians, it is estimated that 300 million Indians cannot afford meat products and consequently have to depend on milk and dairy products for their dietary protein requirements (Bhaskaran 1996). Therefore, given their dietary habits, the cultural significance of milk and dairy products, and their income levels, Indians have a great propensity to consume dairy products. Given the growing urban population, increasing consumer income, and changing lifestyles and food habits, demand for value-added and Western-style dairy product like processed cheese and table butter is growing rapidly. With the emergence of organized food retail chains, the greater availability of processed products is expected to boost sales of packaged dairy products (Rabobank International 2002).

Countries in Southeast Asia (Indonesia, Malaysia, the Philippines, Thailand, and Vietnam) mainly depend on imports to satisfy their demand for dairy products. Their domestic dairy industry is far less developed. Because of poor infrastructure in transporta- 
tion and roads and lack of cold storage, dairy products are difficult to distribute outside of producing areas. Dairy consumption is constrained by limited supply, low income, dietary habits, and poor marketing capabilities. However, this situation is evolving. Some programs and campaigns launched by the countries' governments, such as school milk programs and public awareness programs, have improved the awareness of the importance of consuming milk and helped promote the consumption of dairy products. Moreover, given population and income growth, the demand for dairy products in Southeast Asian countries is increasing and outpacing the supply. Consequently, imports in these countries are also increasing.

Because of high prices and limited supply, milk is perceived as a luxury product in Indonesia. Powdered milk and ready-to-drink milk products are mainly consumed by middle- to upper-income citizens (USDA 2002a). All dairy plants in Indonesia are located on the island of Java. Because of poor infrastructure in transportation and roads and lack of refrigeration, 70 percent of dairy products are available and consumed only in urban areas of Java (USDA 2002a). The economic crisis of 1997-98 drew milk consumption down from $2.86 \mathrm{~kg}$ per capita in 1990 to $1.26 \mathrm{~kg}$ per capita in 2000 . The government of Indonesia promotes milk consumption through a targeted school milk program, subsidized distribution of sweetened condensed milk, and other informational activities. With government promotion and economic recovery, the demand for dairy products is on the path to recovery.

Malaysians consume more dairy products than people in other Southeast Asian countries do, although its consumption is still low by world standards. Increased consumption is fueled by the growth in the number of city dwellers and household income. Meanwhile, the Malaysian government has attempted various programs to improve public awareness and consumption of dairy products. The increased interest in baking and the increased Western influence have expanded Malaysians' demand for butter (USDA 2001a). And Western fastfood chains have helped speed the acceptance of cheese by serving products like cheeseburgers and pizza (USDA 2000). Brand names, quality, price, and availability are important in consumers' buying decisions (USDA 2000).

Philippine milk and dairy products consumption is low largely because of limited supply and the low purchasing power of the average Filipino. According to a report by 
the National Statistical Coordination Board in 2000, about two of every five Filipino families live in poverty (USDA 2001b). Meanwhile, nearly half of all Filipino children are malnourished, with one in three moderately to severely underweight (USDA 2001b). Given a population of 86 million with a growth rate of about 2 percent, a recovering economy, and the government's effort to increase dairy consumption and fight malnutrition, Philippine dairy consumption is growing.

The Thai government launched a campaign to fight malnutrition in rural children in the 1980s. The general public was encouraged to supplement their children's daily diet with milk and dairy products (Zhang, Kilmer, and Muhammad 2003b). The campaign was very successful and Thai milk consumption increased from $1.82 \mathrm{~kg}$ per capita in 1990 to $7.94 \mathrm{~kg}$ per capita in 2000. The school milk program has become a large contributor to fluid milk consumption and has played an important role in helping the Thai dairy industry survive during the last few years (USDA 2001c). Moreover, foreign tourism in Thailand has influenced Thai tastes in favor of Western food. Sales of cheese and butter depend almost exclusively on the tourism market (Murphy and Tisdell 1996).

As in other Southeast Asian countries, dairy consumption is not traditional in the Vietnamese diet. Vietnam has the least consumption of dairy products in Asia. But over the last decade, rising incomes, increasing numbers of tourists, and increasing availability of dairy products have led to a rise in Vietnamese dairy consumption, especially in milk powder consumption. The Vietnamese consume very little butter and cheese, less than $0.1 \mathrm{~kg}$ per capita. And milk remains beyond the means of most poor rural households.

\section{Dairy Product Supply}

Table 3 shows milk production statistics for the major Asian dairy-producing countries. In the last three decades, milk production in China, India, Indonesia, Japan, South Korea, Thailand, and Vietnam grew rapidly, while Malaysian and Philippine milk production has been stagnant or declining.

Developments in both Japanese and South Korean milk production have been boosted by extensive government support programs and economic growth. The dairy industry is the most highly assisted livestock activity in Japan (Zhang, Kilmer, and Muhammad 2003a). The Japanese government changed from deficiency payments, which subsidized producers with a guaranteed level of milk prices, to direct payments in 2001 
The Outlook for Asian Dairy Markets: The Role of Demographics, Income, and Prices / 9

TABLE 3. Milk production in Asian countries for selected years

\begin{tabular}{lrrrrr}
\hline & \multicolumn{5}{c}{ Milk Production (thousand metric tons) } \\
\cline { 2 - 6 } & $\mathbf{1 9 7 0}$ & $\mathbf{1 9 8 0}$ & $\mathbf{1 9 9 0}$ & $\mathbf{2 0 0 0}$ & $\mathbf{2 0 0 4}$ \\
\hline China & 1959 & 2928 & 7037 & 12374 & 22865 \\
India & 22040 & 31200 & 55675 & 80563 & 91000 \\
Indonesia & 174 & 246 & 598 & 786 & 898 \\
Japan & 4761 & 6505 & 8190 & 8497 & 8350 \\
Malaysia & 32 & 37 & 39 & 37 & 45 \\
Philippines & 25 & 30 & 20 & 10 & 12 \\
South Korea & 54 & 455 & 1754 & 2257 & 2304 \\
Thailand & 3.5 & 30 & 130 & 520 & 825 \\
Vietnam & 24 & 41 & 60 & 84 & 165 \\
\hline Source: FAO 2005. & & & & &
\end{tabular}

Source: FAO 2005.

(USDA 1999b). This change was intended to allow dairy cooperatives and dairy processors to negotiate fluid milk prices directly. However, because dairy cooperators remain powerful, prices are still maintained at higher levels (USDA 2004b). Separate quotas for drinking and manufacturing milk are maintained to prevent market surpluses and price instability. Japan has the highest milk yield per cow in the world. Its dairy cow numbers kept declining over the last decade, averaging 1 percent annually. South Korea's milk production in 1980 was eight times as much as it was in 1970, and milk output in 1990 exhibited a four-fold increase over 1980 levels. The development in the Korean dairy sector was attributed to a government support program called the 10-year Integrated Dairy Development Project, which aimed to expand production by providing financial support to farmers and by establishing dairy processing facilities (USDA 1996). The Korean dairy industry has matured over the last 10 years. Larger farms, modern equipment, and better feeding and management practices have improved productivity, resulting in some milk production surpluses. However, limited domestic processing capacity, unreliable local supplies of raw milk, and high raw milk prices have encouraged imports of dairy products. Both Japan and South Korea utilize import quotas and tariffs to heavily protect their domestic dairy processing industry.

Over the past three decades, China's dairy industry has blossomed from near nonexistence to become one of the world's leaders. Its milk production has increased nearly tenfold, and cow numbers have grown to 14 times the level in 1970. China's annual milk 
production rose to about 19 million metric tons in 2004, a level that ranked China seventh in the world in cow milk production. The increase in China's raw milk production has mainly resulted from dairy herd expansion. Because of environmental and land constraints, Chinese herd expansion mainly takes place on farms with feeding instead of grazing. And low-cost feed, such as corn silage, brewer grains, and grasses/vegetables, is commonly used to reduce costs (Fuller and Beghin 2004). Milk yield per cow has increased only in recent years, by about 72 percent over the last five years. The lack of high-quality cows is a constraint to China's dairy expansion. Only half of the national herd is made up of purebred dairy cattle, and the remaining cows are local crossbreds (USDA 2003a). China joined the World Holstein Association in 2004 in order to improve its dairy genetic stock, and the government announced new polices to encourage dairy sector development (USDA 2004a). Currently, the top five producing areas, Inner Mongolia, Heilongjiang, Hebei, Shandong, and Xinjiang, account for 70 percent of China's total cow milk production (Fuller et al. 2005). One characteristic of China's milk production is its small scale. About 60 to 80 percent of raw milk production originates from small household farms, which typically have two to five cows each and low cow yields. With small-scale production, quality control becomes difficult. Because of concerns about the quality of domestic dairy products, well-off consumers tend to prefer foreign products. A tight milk supply is another constraint for the dairy processing sector. Coupled with sanitation problems, dairy companies have had to rely extensively on imported milk powder as an important supplement to raw milk.

There was substantial growth in Indian milk production in the 1980s and 1990s. The increase in milk production from 22 million metric tons in 1970 to the present level of 91 million metric tons has been largely attributed to organized marketing of milk, popularly known as the "Operation Flood" program, by forming milk producers' cooperative societies in major milk surplus areas (USDA 1995; Sharma and Gulati 2003). This program helps farmers market their milk at stable prices throughout the year and supply adequate fluid milk to urban consumers. At the same time, the government concentrated its efforts on improving the productivity of native cows by artificially inseminating them with imported semen and improving the productivity of various indigenous buffalo breeds by cross-breeding them with semen from high-yielding breeds (USDA 1995). India's milk pricing system is based on fat content. Buffalo milk, having an average 6.9 percent fat, 
obtains a premium over cow's milk, which has a fat content of 4.2 percent. Buffalo is a major source of milk in India, with this milk accounting for over 55 percent of Indian milk output. Despite India's rank as the largest milk producer in the world, the Indian dairy industry is dominated by smallholders with an average of two to three cows, which are vulnerable to either low rainfall or excess monsoon rains. Organized industry accounts for less than 15 percent of the milk produced in India. The rest of the milk is consumed at farm level or sold as fresh, non-pasteurized milk through unorganized channels (Rabobank International 2002). The organized industry has great potential for growth. Since the cow is revered by the majority Hindu population, the culling of cows is banned in most parts of India (Bhaskaran 1996). This situation, along with a scarce feed supply, results in an overstock of cows and low milk yield per cow in India.

Southeast Asian countries do not produce enough fresh fluid milk to satisfy their fresh milk needs. The dairy industry has been plagued with problems in cattle feeding systems, farm management, herd replacement quality, acquisition and distribution systems, and unfavorable weather. Although Southeast Asian governments have provided some aid, such as technical assistance and financial support, those programs do not have the expected results.

Indonesia's domestic milk supply is primarily sourced from small dairy farmers with two to three cows each. Problems such as low productivity, poor milk quality, and a short lactating period for dairy cattle are common to dairy farms. Programs supported by the government and private enterprises to increase milk production have not produced satisfying results (USDA 2003b; Riethmuller et al. 1999). Domestic milk production supplies only 35 percent of the total national demand (USDA 1999a). In contrast to the small scale of dairy farms, the milk processing sector is made up of large and competitive companies (Riethmuller et al. 1999), which process roughly 80 percent of fresh milk produced in Indonesia (USDA 1999a). Indonesia does not produce butter, cheese, and NFD. Domestic fluid milk production is primarily used for WMP production. The Indonesian dairy industry relies on milk solid imports, primarily NFD, to meet domestic demand.

Dairy husbandry and milk production are not indigenous to Malaysia. A small dairy industry was started largely by immigrants from India at the beginning of the twentieth 
century when they brought in their cattle herds. Milk production has been concentrated in the areas of rubber and oil palm plantations (USDA 1999c). In 1971, the Malaysian government introduced the New Economic Policy to support the development of the domestic dairy industry. The government established and operated numerous large dairy enterprises and a system of centralized milk collection centers. In the later 1990s, 60 percent of milk produced was collected and sold through official milk collection centers, and about 65 percent of milk from the official milk collection centers was used for domestic dairy manufacturers (Zhang, Kilmer, and Muhammad 2003b). Currently, the Malaysian government supports the domestic dairy industry through direct investment in farms, school milk programs, and restrictions on entry of imported dairy products (Zhang, Kilmer, and Muhammad 2003b). Despite various attempts by the government and the private sector to expand the dairy industry, it has remained small. Major constraints include low lactation and reproduction performance, the hostile tropical weather conditions, the high cost of quality feed, and poor farm management (USDA 1999c). Malaysia has the lowest milk production per cow in the world, with an average of only about $410 \mathrm{~kg}$ per year in the last decade. Currently, only 5 percent of the milk requirement in Malaysia is met within the country (Zhang, Kilmer, and Muhammad 2003b). Malaysia does not produce other dairy products, such as butter, cheese, NFD, and WMP. Therefore, it heavily relies on imports to meet the domestic consumption. The local dairy products are produced by reconstituting and blending imported milk powder and other ingredients or just repackaging imported products. Investment in the dairy industry in Malaysia is considered to be a risky business and the prospect for future growth is not bright (USDA 1999c).

Only 1 percent of total milk demand in the Philippines is met within the country. To develop the domestic dairy industry, the National Dairy Authority has set up Herd BuildUp and Save-the-Herd programs in recent years to allow for the importation of bulls and cows from Australia, New Zealand, and some Pacific Island states. The imported herds are adapted to the local climate and bred with local cows and caribous for milking purposes (USDA 2002b). The infusion of the imported dairy animals has resulted in marginal increases in local milk production. Moreover, the Non Fat Dry Milk grant provided by the USDA has helped the purchase of imported dairy cattle and the establishment of three new dairy zones, which are expected to boost milk production (USDA 2003c). In 
addition, a national school milk program was launched to create the demand for locally produced milk, which consequently stimulates the development of the local dairy industry. However, an extremely low dairy self-sufficiency level continues to characterize the Philippine dairy industry. The country produces only around 10 thousand metric tons of milk with 5,000 cows in recent years, the lowest numbers in the region. The Philippines does not produce other dairy products, such as butter, cheese, NFD, and WMP. The local dairy industry mainly functions as a reprocessing and repackaging industry. Imports have been consistently dominated by NFD and WMP, which are mainly from Australia and New Zealand.

The Royal Thai Government has promoted raw milk production through price guarantees for raw milk, an import quota allocation for NFD, and a school milk program (Hall, Ehui, and Shapiro 2004). Since the average prices for raw fluid milk are higher than the average production costs, dairy farming is generally profitable (USDA 2004c). Meanwhile, increased consumer demand stimulated by rapid economic, population, and tourism growth have boosted milk production. Milk output has jumped from 30 thousand metric tons to 825 thousand metric tons and the number of cows has increased from 15 to 285 thousand head since 1980. Low productivity, poor management, and endemic livestock disease, however, remain the most common problems in dairy farming in Thailand (Murphy and Tisdell 1996; Hall, Ehui, and Shapiro 2004; USDA 2004c). Particularly, diseases of intensification (for example, mastitis, reproductive disorders, and lameness) are considered to be primary constraints to the Thai diary sector (Hall, Ehui, and Shapiro 2004). Milk yield per cow averaged less than 3,000 kg per year in the last decade, which was partly due to the small size of farms, limited technology, and inappropriate dairy breeds. Domestic raw milk supplies currently meet only half of the total processed fluid milk demand (USDA 2003d) and the rest is supplemented by milk powder. As Thailand does not manufacture NFD and WMP, its consumption is totally sourced from imports.

The dairy industry is also at an early stage in Vietnam. There were less than 65 thousand head of dairy cows by 2004 and over 75 percent were distributed in the south and surrounding Ho Chi Minh City (Tuyen and Giao 2003). From 2000 to 2004, milk output was doubled from this small basis, as the government paid more attention to milk production. The inefficiencies, poor management skills, weak dairy breeding 
stock, and a lack of basic infrastructure are major constraints facing the dairy industry in Vietnam (Zhang, Kilmer, and Muhammad 2003b; Tuyen and Giao 2003). Total domestic milk production in Vietnam meets only about 10 percent of the domestic demand (Zhang, Kilmer, and Muhammad 2003b). Vietnam does not produce other dairy products, such as butter, cheese, NFD, and WMP. Consequently, it totally depends on imports to meet domestic demand.

\section{The Outlook for Asian Dairy Markets}

With the fast-paced economic growth, urbanization, population growth, shift in consumption patterns, and modernization of marketing infrastructures in Asia, it is expected that a substantial increase in dairy consumption will be stimulated and this growth will provide prominent opportunities for world dairy exporters. To capture the dynamics of Asian dairy markets and provide some basis for future policy analysis, an outlook for Asian dairy markets seems pivotal. To fulfill the task, several 10-year projections for Asian dairy markets are generated using the FAPRI international dairy model. Initially, a 10 -year baseline is established. Then the model is shocked with alternative income and technology assumptions.

The FAPRI international dairy model is a partial equilibrium, multi-market model organized along commodity lines with country or regional modules. It contains equations for five commodities: milk, butter, cheese, NFD, and WMP. The detailed model explanation is available on the FAPRI Web site (http://www.fapri.iastate.edu/models). The projections provide a 10-year outlook for world agricultural production, consumption, and trade, assuming continuation of current agricultural policies, average weather conditions, and historical rates of technological change (FAPRI 2005). Table 4 presents an outlook for Asian dairy market in selected years. The complete 10-year outlook is referred to as the FAPRI outlook (2005). To augment the country coverage for this analysis, two more countries, Thailand and Vietnam, are added into the model. Generally, both milk production and consumption show an upward trend in Asian countries in the next decade. And most of the increase in milk production is directed to fluid consumption and the increase in other dairy consumption has to be met by imports. The description of the outlook for Asian dairy markets is presented as follows. 
TABLE 4. Outlook for Asian dairy markets

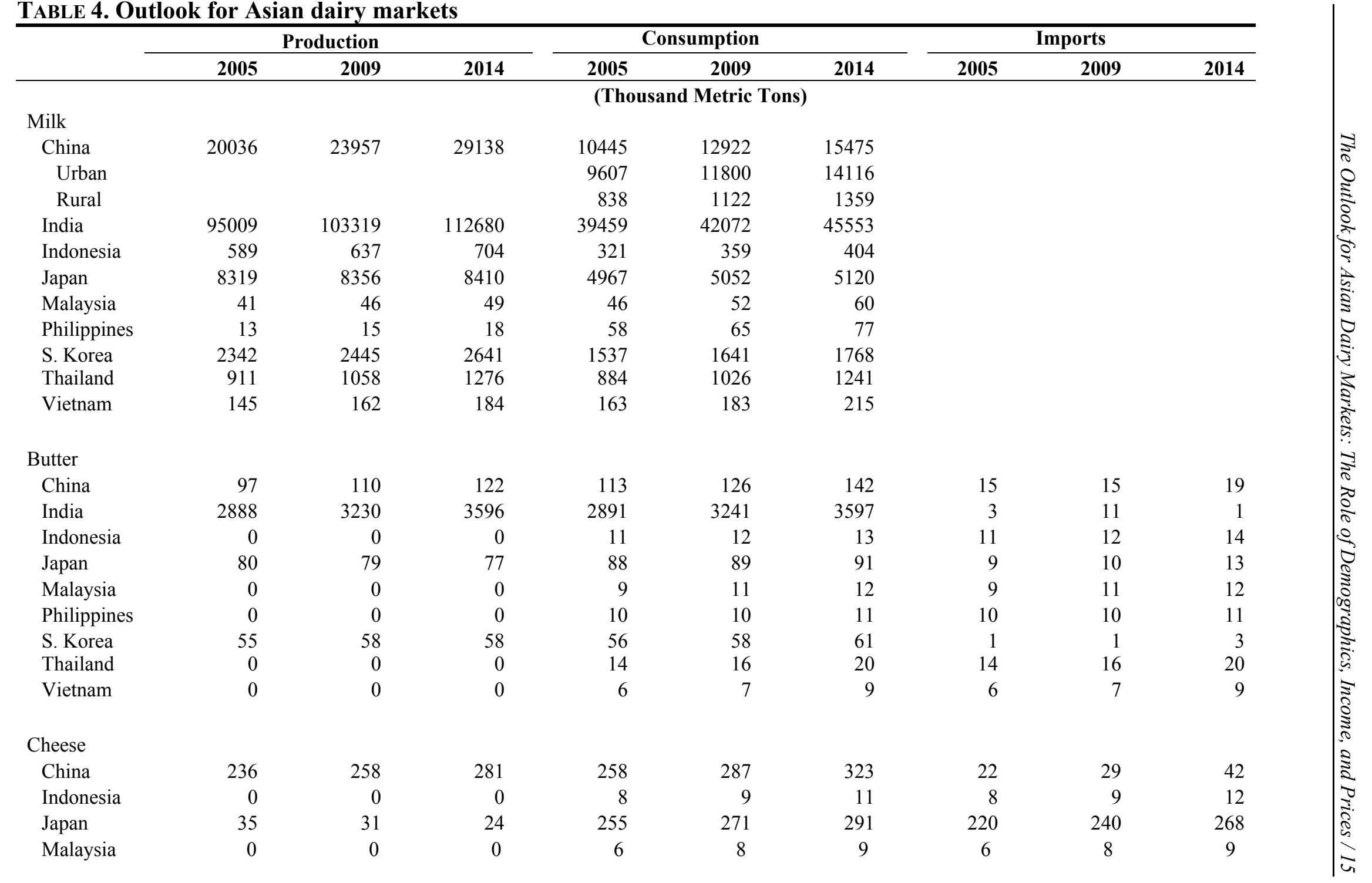


TABLE 4. Continued

\begin{tabular}{|c|c|c|c|c|c|c|c|c|c|}
\hline & \multicolumn{3}{|c|}{ Production } & \multicolumn{3}{|c|}{ Consumption } & \multicolumn{3}{|c|}{ Imports } \\
\hline & 2005 & 2009 & 2014 & 2005 & 2009 & 2014 & 2005 & 2009 & 2014 \\
\hline \multicolumn{10}{|c|}{ (Thousand Metric Tons) } \\
\hline Philippines & 0 & 0 & 0 & 19 & 21 & 25 & 19 & 21 & 25 \\
\hline S. Korea & 22 & 23 & 28 & 65 & 75 & 87 & 43 & 52 & 59 \\
\hline Thailand & 1 & 1 & 1 & 4 & 5 & 6 & 3 & 4 & 5 \\
\hline Vietnam & 0 & 0 & 0 & 1 & 1 & 2 & 1 & 1 & 2 \\
\hline \multicolumn{10}{|l|}{ NFD } \\
\hline China & 76 & 99 & 120 & 144 & 172 & 200 & 68 & 72 & 80 \\
\hline India & 273 & 340 & 410 & 255 & 307 & 358 & -14 & -31 & -49 \\
\hline Indonesia & 0 & 0 & 0 & 90 & 106 & 126 & 90 & 106 & 126 \\
\hline Japan & 179 & 174 & 169 & 213 & 213 & 209 & 33 & 39 & 40 \\
\hline Malaysia & 0 & 0 & 0 & 49 & 59 & 67 & 49 & 59 & 67 \\
\hline Philippines & 0 & 0 & 0 & 130 & 174 & 248 & 130 & 174 & 248 \\
\hline S. Korea & 41 & 41 & 42 & 42 & 41 & 41 & 0.54 & 0.45 & 0.61 \\
\hline Thailand & 0 & 0 & 0 & 85 & 91 & 103 & 79 & 91 & 103 \\
\hline Vietnam & 0 & 0 & 0 & 32 & 39 & 51 & 32 & 39 & 51 \\
\hline \multicolumn{10}{|l|}{ WMP } \\
\hline China & 775 & 904 & 1088 & 910 & 1018 & 1165 & 135 & 114 & 77 \\
\hline Urban & & & & 345 & 392 & 442 & & & \\
\hline Rural & & & & 564 & 626 & 723 & & & \\
\hline Indonesia & 45 & 49 & 56 & 68 & 79 & 92 & 22 & 29 & 36 \\
\hline Malaysia & 0 & 0 & 0 & 86 & 100 & 117 & 86 & 100 & 117 \\
\hline Philippines & 0 & 0 & 0 & 13 & 19 & 24 & 13 & 19 & 24 \\
\hline S. Korea & 6 & 6 & 6 & 6 & 6 & 6 & 0.41 & 0.66 & 0.78 \\
\hline Thailand & 0 & 0 & 0 & 37 & 41 & 48 & 39 & 41 & 48 \\
\hline Vietnam & 0 & 0 & 0 & 45 & 61 & 87 & 45 & 61 & 87 \\
\hline
\end{tabular}

Note: Indian milk production includes both cow and buffalo milk production while for other countries milk production only includes cow milk production. Milk consumption includes cow milk and other milk consumption. 
In the next decade, cow numbers are expected to decline continually in Japan. The improvement in the productivity is expected to offset the decline in the cow numbers, and milk production is expected to increase negligibly. There is an expected sluggish growth in Japanese milk consumption, with only 3 percent growth in 10 years as milk consumption is saturated. Cheese is the only product projected to increase noticeably in consumption, by 16.5 percent, mainly driven by the use in food service and prepared and processed food sectors. As milk output remains leveled and fluid milk consumption increases slightly, milk used in manufacture decreases. Consequently, imports of dairy products are expected to increase, especially imports of cheese, which are projected to increase 24.5 percent over the baseline. South Korean milk production is projected to increase 1.4 percent annually, mainly generated by improved productivity. South Korea's per capita milk consumption is expected to stabilize at around $33 \mathrm{~kg}$ in the next decade, and per capita cheese consumption is projected to increase by 37 percent, reaching $1.8 \mathrm{~kg}$. South Korean cheese imports are projected to increase by 48 percent over the next 10 years. Its NFD imports are constrained by its import quota. As in Japan, butter is still not popular and its consumption is expected to remain stagnant in South Korea.

To meet domestic demands for dairy products, China is expected to significantly increase milk production. In response to efforts by the Chinese government to encourage milk production through better genetics and herd management, Chinese cow yields are expected to increase 3.1 percent annually over the next decade. Rising yields combined with a steady expansion of China's dairy herd result in a projected 4.5 percent annual increase in Chinese milk production, with the level reaching 29 million metric tons by 2014. More than 50 percent of the raw milk output is expected to be directed to fluid use, and nearly 28 percent will be processed into WMP over the next decade. Although urban milk consumption increases dramatically, rural milk consumption is still projected to stay low at about $1.5 \mathrm{~kg}$ per capita by 2014. As domestic WMP becomes more abundant and as consumers substitute fluid consumption for milk powder, WMP imports are expected to decrease over the baseline by 13 percent. Chinese milk, butter, cheese, NFD, and WMP consumption are projected to increase $60,34,29,45$, and 37 percent, respectively, over the next decade. Increased dairy consumption stimulates increased imports of dairy 
products. Chinese butter, cheese, and NFD imports are expected to increase 50, 123, and 19.5 percent, respectively, in the next decade.

In the projection, Indian cow milk production grows 1.6 percent and buffalo milk grows 2.6 percent annually for the next 10 years. The slowdown is caused by limitations in feed and fodder as well as an overstock of cows and low milk yield per cow. Buffalo milk accounts for over 55 percent of Indian milk output and is valued for its high fat content. Roughly 40 percent of raw milk is expected to be directed toward fluid use in India, and the remainder will be processed into butter and other fresh products. Indian butter production is projected to increase 25 percent or 635 thousand metric tons, which accounts for about 64 percent of the growth in the world total butter production. Despite this rapid growth in production, the demand for butter in India is predicted to exceed supplies, leading to limited butter imports throughout the baseline. Indian butter consumption is projected to rise 29 percent in the next decade. As a by-product of butter production, Indian NFD output is projected to increase 57 percent during the projection period, and India's NFD exports are projected to grow 17 percent annually.

In response to governmental efforts and strong demand growth, significant expansion in milk production is expected to occur in Southeast Asian countries, although starting from a very low level. Low productivity, poor management, the small scale of farms, inefficient acquisition and distribution systems, and unfavorable weather will remain as major restrictions to the expansion of the dairy industry in Southeast Asia. Indonesian milk production is projected to increase 21 percent in the next decade, reaching 704 thousand metric tons by 2014. In the meantime, as the economic situation and distribution infrastructure for dairy products develop, dairy consumption is expected to improve. Indonesian NFD and WMP consumption are expected to increase 45 and 41 percent, respectively. There are slight increases in milk cow numbers and yield per cow in Malaysia. As a result, its milk production is projected to rise from 38 thousand metric tons in 2004 to 49 thousand metric tons in 2014. Tremendous growth appears in NFD and WMP consumption, with 41 and 43 percent growth, respectively. Philippine milk production is projected to increase by 50 percent from a very low basis, reaching 18 thousand metric tons by 2014. Significant growth is expected in the Philippines' NFD consumption; it is projected to more than double in the next decade. Thai milk production and consumption are expected to grow at the same pace, 
The Outlook for Asian Dairy Markets: The Role of Demographics, Income, and Prices / 19

with a 4 percent annual growth rate. The increase in milk output will result from the growth in both cow numbers and productivity. NFD consumption is projected to increase 27 percent and WMP consumption is projected to increase 29 percent. Vietnamese milk production is projected to increase steadily, in line with increased consumption, with an annual growth rate of 3 percent. NFD consumption is projected to increase by 70 percent, and WMP consumption is expected to more than double.

As the increase in milk output in Southeast Asian countries is mainly directed toward fluid milk consumption, these countries are expected to continuously depend on imports to meet their domestic demands for other dairy products. They will increase their share of world total NFD imports, from 32 percent in 2004 to 46 percent in 2014, along with increases in their domestic demands. China and Japan are expected to account for about 9 percent of the NFD import market by the end of the baseline. Together, these seven countries are projected to generate virtually all of the growth in the world NFD trade during the projection period. While Chinese WMP imports decline, Southeast Asia is projected to increase its imports 4.9 percent annually. Steady growth is also expected to occur in Southeast Asian butter and cheese imports, with increases of 3.4 percent in butter and 3.9 percent in cheese imports annually over the baseline. However, because of dietary habits, butter and cheese consumption in Southeast Asia will still be very limited.

\section{A Decomposition of Dairy Product Demand Changes}

With the significant growth in Asian dairy demand, it is natural to ask what the driving forces are behind the projected growth of Asian dairy consumption. Projected changes in demand over time account for all of the changes in factors affecting demand, such as price, income, and demographics. For analytical purposes, it is useful to evaluate the effects of those factors separately and then identify the driving sources of the demand changes. Partial elasticity analysis cannot provide accurate information about demand changes because it measures changes in a ceteris paribus manner (Karagiannis and Velentzas 2004). Therefore, it is necessary to undertake a decomposition analysis of demand changes using an alternative framework.

Using Heien and Wessells's (1988) approach and based on the demand equations in the FAPRI models, projected changes in the dairy demand over time are decomposed into 
the following effects: price, income/expenditure, Consumer Price Index (CPI), exchange rate, and population. Given the fact that some Asian countries, more or less, depend on imports to meet domestic demand, the exchange rate affects the dairy demand through the import prices. And CPI is introduced into the equations by deflating prices.

Consider a country's demand function for the $i$ th dairy commodity, $y_{i}=y_{i}(\mathbf{x})$. In this function $\mathbf{X}$ is an $\left(\mathrm{n}_{\mathrm{i}} \times 1\right)$ vector of independent variables that affect the country's dairy demand. Based on Heien and Wessells's approach, the annual rate of change of the total is the elasticity-weighted sum of the annual rates of change of independent variables:

$$
r\left(y_{i}\right)=\sum_{j=1}^{n_{i}} \varepsilon_{i j} r\left(x_{j}\right),
$$

where $r(\cdot)$ is the annual rate of change of the corresponding variable and $\varepsilon_{i j}$ is the demand elasticity with respect to the independent variables,

$$
\varepsilon_{i j}=\frac{\partial y_{i}}{\partial x_{j}} \frac{x_{j}}{y_{i}} .
$$

In the FAPRI model, total consumption is modeled as the product of population and per capita consumption; and per capita consumption is a function of affecting factors, including price, real income/expenditure, exchange rate, and CPI.

The decomposition analysis results are reported in Table 5, which gives the contributions of the changes in affecting factors to projected dairy consumption growth in the next 10 years. It is assumed that the world price is exogenous to the countries, which implies that Asian countries are small players in world dairy markets. Predicted values in Table 5 give the predicted annual rates of growth in quantity consumed by each country over the 2005-2014 period, which is the sum of all rows in the same column for each country; and the actual values in the last row give the actual rates of growth, which are calculated directly from the projections. The discrepancy between the predicted and actual values is caused by the adjustments in the model, which aim to accommodate some factors not included in the model, and by the approximation, which uses the first difference in equation (1) as well. 
TABLE 5. Decomposition of average annual growth of demand for milk and dairy products in Asian countries, 2005-2014 (percent)

\begin{tabular}{|c|c|c|c|c|c|}
\hline & Milk & Butter & Cheese & NFD & WMP \\
\hline \multicolumn{6}{|l|}{ China } \\
\hline Population & & 0.51 & 0.48 & 0.45 & \\
\hline Urban & 0.16 & & & & 0.24 \\
\hline Rural & 0.00 & & & & 0.14 \\
\hline Expenditure & & 1.50 & 1.88 & 2.26 & \\
\hline Urban & 2.78 & & & & 0.88 \\
\hline Rural & 0.27 & & & & 2.04 \\
\hline World butter price & & -0.25 & & & \\
\hline World cheese price & & & -0.02 & & \\
\hline World NFD price & & & & -0.53 & \\
\hline World WMP price & -0.45 & & & & 0.14 \\
\hline CPI & 0.86 & 0.67 & 0.17 & 1.00 & -0.37 \\
\hline Exchange rate $^{\mathrm{a}}$ & 0.53 & 0.41 & 0.10 & 0.62 & -0.03 \\
\hline Australian exchange rate ${ }^{b}$ & -0.23 & -0.13 & -0.04 & -0.24 & 0.07 \\
\hline Predicted & 3.93 & 2.72 & 2.56 & 3.56 & 3.11 \\
\hline Actual & 4.81 & 2.30 & 1.90 & 3.12 & 3.21 \\
\hline \multicolumn{6}{|l|}{ India } \\
\hline Real GDP & 0.40 & 1.17 & & 2.19 & \\
\hline Population & 1.22 & 1.03 & & 0.79 & \\
\hline World butter price & -0.02 & -0.33 & & & \\
\hline World NFD price & -0.05 & & & -0.30 & \\
\hline CPI & 0.21 & 1.14 & & 0.76 & \\
\hline Exchange rate & -0.04 & -0.23 & & -0.16 & \\
\hline Australian exchange rate & -0.03 & -0.18 & & -0.14 & \\
\hline Predicted & 1.69 & 2.60 & & 3.15 & \\
\hline Actual & 1.90 & 2.59 & & 3.87 & \\
\hline \multicolumn{6}{|l|}{ Indonesia } \\
\hline Real GDP & 1.44 & 0.72 & 2.16 & 2.88 & 2.40 \\
\hline Population & 0.91 & 1.04 & 0.71 & 0.52 & 0.65 \\
\hline World butter price & 0.00 & 0.00 & & & \\
\hline World cheese price & 0.00 & & 0.00 & & \\
\hline World NFD price & 0.00 & & & 0.00 & \\
\hline World WMP price & & & & & 0.00 \\
\hline CPI & 0.53 & 0.64 & 0.58 & 0.53 & 0.87 \\
\hline Exchange rate & 0.00 & 0.00 & 0.00 & 0.00 & 0.00 \\
\hline Australian exchange rate & 0.00 & 0.00 & 0.00 & 0.00 & 0.00 \\
\hline Predicted & 2.88 & 2.40 & 3.45 & 3.93 & 3.92 \\
\hline Actual & 2.48 & 2.40 & 3.38 & 3.79 & 3.53 \\
\hline
\end{tabular}


TABle 5. Continued

\begin{tabular}{|c|c|c|c|c|c|}
\hline & Milk & Butter & Cheese & NFD & WMP \\
\hline \multicolumn{6}{|l|}{ Japan } \\
\hline Real GDP & 0.33 & 0.21 & 1.28 & 0.34 & \\
\hline Population & -0.08 & -0.08 & -0.03 & -0.08 & \\
\hline World butter price & 0.05 & -0.03 & 0.00 & & \\
\hline World cheese price & -0.01 & & -0.01 & & \\
\hline World NFD price & & & & 0.00 & \\
\hline CPI & 0.09 & 0.24 & 0.21 & 0.00 & \\
\hline Exchange rate & 0.00 & -0.06 & 0.06 & 0.00 & \\
\hline Australian exchange rate & 0.01 & -0.02 & -0.02 & 0.00 & \\
\hline Predicted & 0.38 & 0.27 & 1.49 & 0.26 & \\
\hline Actual & 0.31 & 0.30 & 1.54 & -0.41 & \\
\hline \multicolumn{6}{|l|}{ Malaysia } \\
\hline Real GDP & 1.88 & 2.35 & 2.35 & 1.41 & 2.82 \\
\hline Population & 1.04 & 0.87 & 0.87 & 1.22 & 0.70 \\
\hline World butter price & -0.04 & -0.17 & & & \\
\hline World cheese price & -0.04 & & -0.11 & & \\
\hline World NFD price & -0.05 & & & -0.16 & \\
\hline World WMP price & & & & & -0.18 \\
\hline CPI & 0.20 & 0.21 & 0.43 & 0.14 & 0.16 \\
\hline Exchange rate & 0.14 & 0.12 & 0.23 & 0.08 & 0.09 \\
\hline Australian exchange rate & -0.11 & -0.09 & -0.18 & -0.07 & -0.07 \\
\hline Predicted & 3.02 & 3.29 & 3.59 & 2.63 & 3.51 \\
\hline Actual & 3.00 & 3.23 & 3.58 & 3.64 & 3.51 \\
\hline \multicolumn{6}{|l|}{ The Philippines } \\
\hline Real GDP & 2.30 & 0.46 & 1.61 & 0.46 & 1.55 \\
\hline Population & 0.85 & 1.54 & 1.11 & 1.54 & 1.13 \\
\hline World butter price & -0.17 & -0.17 & & & \\
\hline World cheese price & -0.17 & & -0.10 & & \\
\hline World NFD price & -0.21 & & & -0.20 & \\
\hline World WMP price & & & & & -0.49 \\
\hline CPI & 1.89 & 0.68 & 1.32 & 0.56 & 1.37 \\
\hline Exchange rate & -0.51 & -0.10 & -0.19 & -0.09 & -0.21 \\
\hline Australian exchange rate & -0.47 & -0.09 & -0.18 & -0.08 & -0.19 \\
\hline Predicted & 3.52 & 2.32 & 3.56 & 2.19 & 3.16 \\
\hline Actual & 3.00 & 2.19 & 3.40 & 7.51 & 6.82 \\
\hline \multicolumn{6}{|l|}{ South Korea } \\
\hline Real GDP & 0.25 & 0.50 & 2.50 & 0.15 & 0.30 \\
\hline Population & 0.27 & 0.26 & 0.14 & 0.28 & 0.27 \\
\hline World butter price & -0.04 & -0.30 & & & \\
\hline World cheese price & -0.03 & & -0.18 & & \\
\hline
\end{tabular}


The Outlook for Asian Dairy Markets: The Role of Demographics, Income, and Prices / 23

TABLE 5. Continued

\begin{tabular}{|c|c|c|c|c|c|}
\hline & Milk & Butter & Cheese & NFD & WMP \\
\hline World NFD price & -0.08 & & & -0.22 & \\
\hline World WMP price & & & & & -0.50 \\
\hline CPI & 0.37 & 0.67 & 1.33 & 0.40 & 1.03 \\
\hline Exchange rate & 0.01 & 0.02 & 0.04 & 0.01 & 0.03 \\
\hline Australian exchange rate & -0.12 & -0.16 & -0.32 & -0.10 & -0.25 \\
\hline Predicted & 0.63 & 0.98 & 3.51 & 0.52 & 0.88 \\
\hline Actual & 1.64 & 0.96 & 3.49 & -0.48 & 0.87 \\
\hline \multicolumn{6}{|l|}{ Thailand } \\
\hline Real GDP & 3.50 & 0.30 & 2.75 & 2.53 & 2.76 \\
\hline Population & 0.25 & 0.30 & 0.35 & 0.38 & 0.35 \\
\hline World butter price & 0.00 & -0.12 & & & \\
\hline World cheese price & & & -0.12 & & \\
\hline World NFD price & 0.00 & & & -0.62 & 0.36 \\
\hline World WMP price & 0.00 & & & 0.61 & -0.36 \\
\hline CPI & 0.01 & 0.27 & 0.73 & & \\
\hline Exchange rate & 0.00 & 0.20 & 0.56 & & \\
\hline Australian exchange rate & 0.00 & -0.06 & -0.23 & 0.03 & -0.02 \\
\hline Predicted & 3.75 & 3.73 & 4.05 & 2.94 & 3.09 \\
\hline Actual & 4.51 & 3.81 & 3.77 & 2.45 & 2.55 \\
\hline \multicolumn{6}{|l|}{ Vietnam } \\
\hline Real GDP & 2.59 & 3.96 & 1.81 & 5.01 & 7.89 \\
\hline Population & 0.62 & 0.42 & 0.73 & 0.27 & -0.15 \\
\hline World butter price & -0.16 & -0.01 & & & \\
\hline World cheese price & & & -0.41 & & \\
\hline World NFD price & -0.23 & & & -0.57 & \\
\hline World WMP price & & & & & -0.48 \\
\hline CPI & 0.87 & 0.03 & 2.95 & 1.13 & 0.95 \\
\hline Exchange rate & -0.24 & -0.01 & -0.80 & -0.31 & -0.26 \\
\hline Australian exchange rate & -0.19 & -0.01 & -0.76 & -0.26 & -0.24 \\
\hline Predicted & 3.27 & 4.38 & 3.51 & 5.27 & 7.71 \\
\hline Actual & 3.36 & 4.61 & 4.56 & 5.44 & 8.05 \\
\hline
\end{tabular}

${ }^{\mathrm{a}}$ The exchange rate is the local currency to the U.S. dollar.

${ }^{\mathrm{b}}$ The Australian exchange rate is Australian currency to the U.S. dollar.

The income or expenditure effect is positive in all cases, as all commodities are modeled as normal goods in the FAPRI model. The magnitude of income or expenditure effect among commodity categories is different because of differences in income or expenditure elasticities. Because of the significant gap between urban and rural area, China's milk and 
WMP consumption are categorized into urban and rural consumption. ${ }^{2}$ The contribution of the change in China's urban expenditure is projected to be greater than other components for the growth of Chinese milk consumption, while the contribution of the change in rural expenditure is projected to be greater than other components for the growth of Chinese WMP consumption. The effect of the increase in expenditure is also expected to be the main driving force in Chinese other-dairy-demand growth, explaining more than 55 percent of the overall demand change over the period. Urbanization does have a positive effect on the growth of Chinese milk and WMP consumption, as the effect of urban population growth is projected to outweigh that of rural population growth.

Population growth is projected to have a systematic positive effect on the growth of dairy demand. In the next decade, Japan's population will trend downward but the increase of per capita consumption of dairy product is expected to outpace the decline of population. The driving force in the change of Japanese dairy consumption is going to be the growth of real gross domestic product (GDP). It is expected to explain over 80 percent of overall dairy consumption growth. Population growth is expected to be the main driving force in explaining the changes in Indian milk consumption. It is expected to account for 72 percent of the changes in Indian milk consumption. The growth of real GDP and population are expected to be two major factors affecting Indian butter consumption. They are expected to account for 45 and 40 percent of the growth in Indian butter consumption, respectively. The growth of real GDP is expected to be far less important in milk consumption change than in butter and NFD consumption changes in India. In other Asian countries, population growth and real GDP growth also turn out to be the major contributors to the dairy demand growth. For example, real GDP growth is expected to be the sole cause of 2.8 percent out of a total 3.5 percent growth in WMP demand in Malaysia; and population growth is expected be the sole cause of 1.5 percent out of a total 2.3 percent growth in butter demand in the Philippines. Real GDP and population growth together are projected to explain at least 60 percent of the dairy demand changes in each country.

In the FAPRI model, the Australian price is treated as the representative world price, except for milk, and solved through world market equilibrium. Since Asian countries more or less depend on imports to meet domestic demand, however, their demand levels are not as elastic in price as in income and hence the increase in the world price is ex- 
pected to have very modest negative effects on the growth of dairy demand. For example, world NFD price growth is expected to cause a 0.16 percent decrease in Malaysian NFD demand, which is expected to have a total 2.63 percent growth. Generally, an increase in the CPI has a positive effect on dairy demand growth, in that CPI growth decreases the dairy prices relative to all other goods in the economy and subsequently increases dairy demand. But the effect is expected to be very limited. Values of imports/exports are expressed in U.S. dollars in the model, so both local and Australian exchange rates relative to U.S. dollars enter into the models. For the same reason that the effects of prices are moderate, aggregated effects of both exchange rates are expected to be very small on the growth of Asian dairy demand.

\section{Impacts of Income and Technology Changes on World Dairy Markets}

In the decomposition analysis of Asian dairy demand, the small-country case is assumed and the world price is treated as exogenous to each country. To capture the effects of Asian countries' development on world dairy markets, this assumption is released in the following analysis. The FAPRI international dairy model is shocked with alternative income and technology assumptions: (1) a 1 percent increase in each Asian country's income level, (2) a 1 percent increase in technology measured by the yield per cow in Asian countries, and (3) a 1 percent increase in both income and technology in each Asian country, relative to the outlook levels in next 10 years. Besides income growth being an important driving force of dairy demand change, the dynamic of the Asian economy is another reason for choosing a higher income level as a scenario. Given relatively low productivity (except in Japan and South Korea) and increasing pressures on land and the environment, Asian countries are motivated to improve their productivity. For this reason, technology change is picked up as another alternative. The simulations are conducted by shocking the dairy model with those additional changes. The simulation results are compared with the outlook discussed previously to assess the impacts of Asian income and technology change on Asian dairy demand and world dairy prices.

Table 6 presents the simulation results. Consistent with the decomposition analysis, income growth is expected to boost Asian dairy demand, especially of cheese and WMP. Given a 1 percent increase in income, cheese consumption will increase 0.45 percent and 
TABLE 6. Impacts of Asian income and technology change on Asian dairy demand and world dairy prices, 2005-2014 (percent)

\begin{tabular}{|c|c|c|c|c|c|}
\hline & \multicolumn{5}{|c|}{ Asian Dairy Demand Change } \\
\hline & Fluid milk & Butter & Cheese & NFD & WMP \\
\hline Income change $(1 \%)$ & 0.18 & 0.12 & 0.45 & 0.19 & 0.40 \\
\hline Technology change (1\%) & 0.11 & 0.53 & 0.08 & 0.13 & 0.06 \\
\hline \multirow[t]{3}{*}{$\begin{array}{l}\text { Income growth and } \\
\text { technology change }\end{array}$} & 0.29 & 0.64 & 0.52 & 0.32 & 0.46 \\
\hline & \multicolumn{5}{|c|}{ World Dairy Price Change } \\
\hline & & Butter & Cheese & NFD & WMP \\
\hline Income change (1\%) & & 0.44 & 0.23 & 0.93 & 1.05 \\
\hline Technology change $(1 \%)$ & & -2.51 & -0.70 & -1.07 & -1.90 \\
\hline Income growth and & & & & & \\
\hline technology change & & -2.06 & -0.46 & -0.14 & -0.83 \\
\hline
\end{tabular}

WMP consumption will increase 0.39 percent. For each individual country or each commodity, the income shock has different impacts. For example, 1 percent growth in expenditure in China is expected to cause a 0.6 percent increase in milk consumption and a 0.4 percent increase in WMP consumption but a smaller increase in butter and NFD consumption. In addition, the income shock will cause a decline in Korean WMP consumption. Detailed individual country and commodity consumption changes are presented in the Appendix. As demand increases and supply remains stable, import demand is expected to increase and consequently push up the world dairy prices. Given a 1 percent increase in Asian income, world NFD and WMP prices are expected to increase 0.9 and 1 percent, respectively. The price changes in NFD and WMP are much bigger than the changes in the butter and cheese prices. The reason is that, as big NFD and WMP importers, Asian countries account for 40 percent of total world NFD net imports and 15 percent of total world WMP net imports. Therefore, a small percentage change in milk powder imports can cause a much bigger change in world milk powder prices than in butter and cheese prices.

With a technology change that increases the yield per cow, Asian domestic milk output is projected to increase and consequently decrease Asia's dependence on imports. As stated previously, since Asia is a big importer of milk powder, a slight change in its import levels can cause a large change in world prices. Moreover, as more fluid milk is available and substitutes for WMP consumption, WMP demand will decline more. Therefore, there are bigger expected decreases in both world NFD and WMP prices, of 1.15 and 1.95 percent, 
respectively. The world butter price is expected to decrease by about 2.5 percent, given a 1 percent growth in yield per cow in Asia. This substantial change is attributed to two factors. First, India, as a major consumer of butter in Asia, is expected to become self-sufficient in butter and even be able to export some butter to the world markets given a 1 percent rise in its milk productivity. Second, as a by-product of NFD, butter domestic supply in other Asian countries is also expected to increase as NFD production increases. The surplus supply of butter is expected to decrease aggregate Asian butter imports. These two factors will pressure the world butter price downward drastically. The technology change is also expected to boost domestic dairy consumption by lowering prices and increasing availability of dairy products to Asian people. Given a 1 percent rise in milk productivity, Asian butter consumption is expected to increase the most, by 0.53 percent. Indian butter consumption will account for almost all of this increase. Other countries' butter consumptions are expected to increase from a very small basis.

Income growth and technology improvement combined can cause an increase in Asian dairy demand but a decrease in world dairy prices. This is because technology change can have a bigger effect on world dairy prices than can income growth.

\section{Concluding Comments}

The outlook suggests that both Asian dairy consumption and supply show upward trends in the next decade. The decomposition analysis shows that Asian dairy demand growth in the next decade is projected to be mostly driven by income and population growth in Asia. Although increases in world prices have negative effects on Asian dairy demand growth, the effect is expected to be relatively modest. Therefore, besides keeping the dairy price reasonable, the governments of Asian countries seeking to increase domestic dairy consumption could focus on the improvement of the domestic economy. In addition, with improvement in the domestic economy and infrastructure, transportation and cold storage are expected to improve and thus expand access to fresh dairy products for more consumers. When Asian dairy demand is increased, the world dairy price would also increase. This situation provides a good opportunity for world dairy exporters who can benefit not only from higher selling prices but also from expanding markets. 
Many Asian countries' governments are trying to increase domestic milk production. The simulations indicate that, with technology change, Asian dairy supply would increase and consequently Asian dairy demand would also be enhanced because of lower prices and increased availability of dairy products. More domestic supply, however, would decrease Asian dairy imports or increase exports and consequently would dampen world dairy prices, especially for butter and milk powder, for which prices would drop drastically. This would create a challenge to world dairy exporters in that they would have to face more competitive export markets.

Our analysis has some limitations. Diet habit changes are not captured. As in the case of Japan and South Korea, milk consumption stays stagnant after it reaches about 35-40 kg per capita. Compared with other industrialized countries, per capita dairy consumption levels in these two countries are much lower and income differences are not able to explain such between-country differences in consumption patterns. This indicates that different dietary cultures are determining factors after income reaches a certain level in Asian countries. Therefore, communication of healthy and nutritious information about dairy products to consumers is also an important factor affecting Asian dairy consumption. In addition, urbanization is only considered in the case of China because of information limitations. Southeast Asian countries are categorized as developing countries and in an urbanization process. Infrastructure and accessibility are still constraints for the expansion of dairy consumption in those countries. Generally, urban residents have more access to dairy products than do rural residents. The issues of dietary habits and urbanization need to be further addressed in the future, as more data become available on these two sources of changes. 


\section{Endnotes}

1. The per capita consumption is the simple sum of all dairy products and not in terms of milk equivalent.

2. Because of data limitations, such dichotomy, although very interesting, is not provided for other Asian developing countries. 


\section{Appendix}

\section{Impacts of Income and Technology Change on Asian Countries' Dairy Demand, 2005-2014}

\begin{tabular}{|c|c|c|c|c|c|}
\hline & \multicolumn{5}{|c|}{ Income Change (1\%) } \\
\hline & Fluid Milk & Butter & Cheese & NFD & WMP \\
\hline China & 0.63060 & 0.12702 & 0.23691 & 0.02921 & 0.40428 \\
\hline India & 0.04297 & 0.11533 & & 0.23975 & \\
\hline Indonesia & 0.20963 & 0.13352 & 0.41804 & 0.48467 & 0.28523 \\
\hline Japan & 0.18284 & 0.10772 & 0.70160 & 0.14815 & \\
\hline Malaysia & 0.32975 & 0.43287 & 0.43045 & 0.20643 & 0.48293 \\
\hline Philippines & 0.20180 & 0.03437 & 0.28339 & -0.01401 & 0.02151 \\
\hline South Korea & -0.01967 & 0.01206 & 0.40769 & -0.08086 & -0.26474 \\
\hline Thailand & 0.64148 & 0.56108 & 0.45535 & 0.43380 & $-1.8 \mathrm{E}-07$ \\
\hline \multirow[t]{3}{*}{ Vietnam } & 0.21509 & 0.48378 & 0.04330 & 0.43310 & 0.83345 \\
\hline & \multicolumn{5}{|c|}{ Technology Change (1\%) } \\
\hline & Fluid Milk & Butter & Cheese & NFD & WMP \\
\hline China & 0.32199 & 0.41915 & 0.03737 & 0.31681 & -0.02155 \\
\hline India & 0.05479 & 0.54993 & & 0.18502 & \\
\hline Indonesia & 0.20731 & 0.38235 & 0.09427 & 0.13349 & 0.39122 \\
\hline Japan & 0.00773 & 0.07353 & 0.04153 & 0.04735 & \\
\hline Malaysia & 0.19316 & 0.38235 & 0.20962 & 0.10851 & 0.21180 \\
\hline Philippines & 0.86661 & 0.37979 & 0.20123 & 0.13349 & 0.57871 \\
\hline South Korea & 0.17091 & 0.51012 & 0.27960 & 0.13023 & 0.59805 \\
\hline Thailand & 0.02121 & 0.19903 & 0.20145 & -0.28159 & $-1.8 \mathrm{E}-07$ \\
\hline Vietnam & 0.40055 & 0.53836 & 0.67057 & 0.35625 & 0.57630 \\
\hline
\end{tabular}


The Outlook for Asian Dairy Markets: The Role of Demographics, Income, and Prices / 31

\section{Continued}

\begin{tabular}{lccccc}
\hline & Fluid Milk & \multicolumn{4}{l}{ Income and Technology Change (1\%) } \\
& Butter & Cheese & NFD & WMP \\
\hline China & 0.94862 & 0.54219 & 0.27379 & 0.33957 & 0.38157 \\
India & 0.09726 & 0.66140 & & 0.42269 & \\
Indonesia & 0.41361 & 0.51196 & 0.51124 & 0.61601 & 0.66883 \\
Japan & 0.19052 & 0.18053 & 0.74243 & 0.19461 & \\
Malaysia & 0.52056 & 0.81245 & 0.63770 & 0.31290 & 0.69102 \\
Philippines & 1.05459 & 0.40991 & 0.48205 & 0.11667 & 0.58743 \\
South Korea & 0.14840 & 0.51637 & 0.68406 & 0.04654 & 0.31843 \\
Thailand & 0.66156 & 0.75874 & 0.65425 & 0.15854 & $-1.8 \mathrm{E}-07$ \\
Vietnam & 0.61225 & 1.01837 & 0.70531 & 0.78535 & 1.40291 \\
\hline
\end{tabular}




\section{References}

Bhaskaran. S., 1996. “Culture’s Consequences: Dairy Market Opportunities in India.” Marketing Bulletin 7: 39-50.

Campo, I.S., and J. Beghin. 2005. "Dairy Food Consumption, Production and Policy in Japan.” Food Pol$i c y$, forthcoming.

Food and Agricultural Policy Research Institute (FAPRI). 2005. FAPRI 2005 U.S. and World Agricultural Outlook. Staff Report 1-05. Food and Agricultural Policy Research Institute, Iowa State University and University of Missouri-Columbia. Ames, IA.

Food and Agriculture Organization of the United Nations (FAO). 2005. Statistical database.

Fuller, F., and J. Beghin. 2004. “China’s Dairy Market: Consumer Demand Survey and Supply Characteristics." CARD Working Paper 04-SR 99. Center for Agricultural and Rural Development, Iowa State University.

Fuller, F., J Huang, H. Ma, and S. Rozelle. 2005. “The Rapid Rise of China's Dairy Sector: Factors Behind the Growth in Demand and Supply," CARD Working Paper 05-WP 394. Center for Agricultural and Rural Development, Iowa State University.

Hall, D., S. Ehui, and B. Shapiro. 2004. "Economic Analysis of the Impact of Adopting Herd Health Control Programs on Smallholder Dairy Farms in Central Thailand.” Agricultural Economics 31: 335-42.

Heien, D.M., and C. Wessells. 1988. "The Demand for Dairy Products: Structure, Prediction, and Decomposition.” American Journal of Agricultural Economics 70: 219-28.

JETRO (Japan External Trade Organization). 1999. “Japanese Market Report-Regulations \& PracticesCheese.” http://www.jetro.go.jp/en/market/reports/jmr/030.pdf (accessed June 2005).

Karagiannis, G., and K. Velentzas. 2004. “ Decomposition Analysis of Consumers' Demand Changes: An Application to Greek Consumption Data.” Applied Economics 36: 497-504.

Ma, H., and A. Rae. 2003. "Projections of Dairy Product Consumption and Trade Opportunities in China." China Agriculture Working Paper 2/03. Center for Applied Economics and Policy Studies, Massey University, New Zealand.

Murphy, T., and C. Tisdell. 1996. "An Overview of Trends and Developments in the Thai Dairy Industry." Research paper and report in animal health economics. Department of Economics, University of Queensland.

Rabobank International. 2002. Indian Dairy Study-Opportunities in the Indian Dairy Industry. Special report. Utrecht, The Netherlands.

Rae, A. 1997. " Changing Food Consumption Patterns in East Asia: Implications of the Trend Towards Livestock Products." Agribusiness 13: 33-44. 
The Outlook for Asian Dairy Markets: The Role of Demographics, Income, and Prices / 33

Riethmuller, P., J. Chai, D. Smith, B. Hutabarat, B. Sayaka, and Y. Yusdja. 1999. "The Mixing Ratio in the Indonesian Dairy Industry." Agricultural Economics 20: 51-56.

Sharma, V., and A. Gulati. 2003. "Trade Liberation, Market Reforms and Competitiveness of Indian Dairy Sector.” MTID Discussion Paper No. 61. International Food Policy Research Institute, Washington, DC.

Song, J., and D. Sumner. 1999. "Dairy Demand, Supply and Policy in Korea: Potential for International Trade.” Canadian Journal of Agricultural Economics 47: 133-42.

Tuyen, D.K., and H. K. Giao. 2003. "Dairy Cattle Production in Vietnam and Development Plan for 20022010." Governmental report. Vietnam Ministry of Agricultural and Rural Development. http://www.agroviet.gov.vn/en/stories/TinTiengAnh/DairyCattleProductionInVietnam.asp (accessed June 7, 2005).

U.S. Department of Agriculture, Foreign Agricultural Service (USDA). 1995. India Dairy Annual 1995. AGR Number IN5109. Washington, DC.

—. 1996. Republic of Korea Dairy Annual 1996. AGR Number KS6027. Washington, DC.

—. 1999a. Indonesia Dairy Annual 1999. GAIN Report Number ID9082. Washington, DC. . 1999b. Japan Dairy Annual 1999. GAIN Report Number JA9148. Washington, DC.

—. 1999c. Malaysia Dairy Annual 1999. GAIN Report Number MY9079. Washington, DC.

—. 2000. Malaysia Dairy and Products Annual 2000. GAIN Report Number MY0055. Washington, DC.

—. 2001a. Malaysia Dairy and Products Annual 2001. GAIN Report Number MY1061. Washington, DC.

—. 2001b. Philippines Dairy and Products Annual 2001. GAIN Report Number RP1059. Washington, DC.

—. 2001c. Thailand Dairy and Products Annual 2001. GAIN Report Number: TH1114. Washington, DC.

- 2002a. Indonesia Dairy and Products Annual 2002. GAIN Report Number ID2025. Washington, DC.

—. 2002b. Philippines Dairy and Products Annual 2002. GAIN Report Number RP2075. Washington, DC.

—. 2003a. China's Dairy Industry Overview 2003. GAIN Report Number CH3814. Washington, DC.

_.2003b. Indonesia Dairy and Products Annual 2003. GAIN Report Number; ID3026. Washington, DC.

. 2003c. Philippines Dairy and Products Annual 2003. GAIN Report Number: RP3061.

Washington, DC.

-2003d. Thailand Dairy and Products Annual 2003. GAIN Report Number: TH3123. Washington, DC.

_. 2004a. China Dairy and Products Annual 2004. GAIN Report Number: CH4050. Washington, DC.

—. 2004b. Japan Dairy and Products Annual 2004. GAIN Report Number: JA4084. Washington, DC.

. 2004c. Thailand Dairy and Products Annual 2004. GAIN Report Number: TH4125. Washington, DC. 
Zhang, X., R. Kilmer, and A. Muhammad. 2003a. "A Descriptive Analysis of Hong Kong, Japan, and South Korea Who Import United States Dairy Products.” MGTC 03-10. International Agricultural Trade and Policy Center, University of Florida.

. 2003b. "A Descriptive Analysis of Selected Southeast Asia Countries That Import United States Dairy Products." MGTC 03-14. International Agricultural Trade and Policy Center, University of Florida.

Zhou, Z., W. Tian, and J. Zhou. 2002. "The Emerging Dairy Economy in China: Production, Consumption and Trade Prospects." Australian Agribusiness Review 10: Paper 8. 